\title{
Revising the basis for planning a new kind of progress: the case of Valencia's city
}

\author{
J. L. Miralles i Garcia \\ Department of Urban Planning, \\ Polytechnic University of Valencia, Spain
}

\begin{abstract}
The paper analyses the contradictions in the regional planning process for revising the basis and criteria for future intervention and management in metropolitan areas such as Valencia with a new type of progress objective. Valencia, the Mediterranean coastal city, is the third largest city in Spain after Madrid and Barcelona. In the metropolitan area of Valencia about 1.3 million people live. "L'Horta de València" is located in the suburban environment of the Valencian metropolitan area; it has agricultural land with high productivity. These agricultural lands include about 10,000 ha of historical fertile land and another 10,000 ha of fertile land irrigated more recent (about XIXs). In this metropolitan area, there are serious conflicts between different land usages mainly urban sprawl such as expansion of building and infrastructures, replacing fertile agricultural land use. In addition, there is strong competition between different urban uses, e.g. port, beach and tourist zones, high speed rail, industrial estates and new buildings zones. In addition, contradictions between sustainability and development are very intense, especially when the development is only an expectation. In 2000, civil society promoted the legislative initiative, "L'Horta de València" Protection Act, while economic development in the period 1997-2007 was based on speculative urban expansion. The main goal of this initiative is to ensure sustainable development while conserving natural resources needed for future generations. This initiative was refused based on two stated main arguments: i) protection would hinder the economic development and ii) elaborate a protection plan with other approaches. At the end of 2010 works of government about regional planning for "Horta de València" protection were finished. However, the plan is not approved yet. From the 2007 crisis, speculative urban expansion resulted in
\end{abstract}


the impoverishment of many people; while, large areas of fertile agricultural land have disappeared.

Keywords: regional planning, green infrastructure, urban redevelopment.

\section{Introduction}

Valencia has historical experience in metropolitan planning [1]. The first plan of the Valencian metropolitan area was the Plan General de Ordenación Urbana de Valencia y su Cintura (Urban Plan of Valencia and around) that was approved in 1946. The plan was managed by a metropolitan organization named Corporación Administrativa Gran Valencia (Administrative Corporation of Great Valencia) created by law in 1946 and decree in 1949.

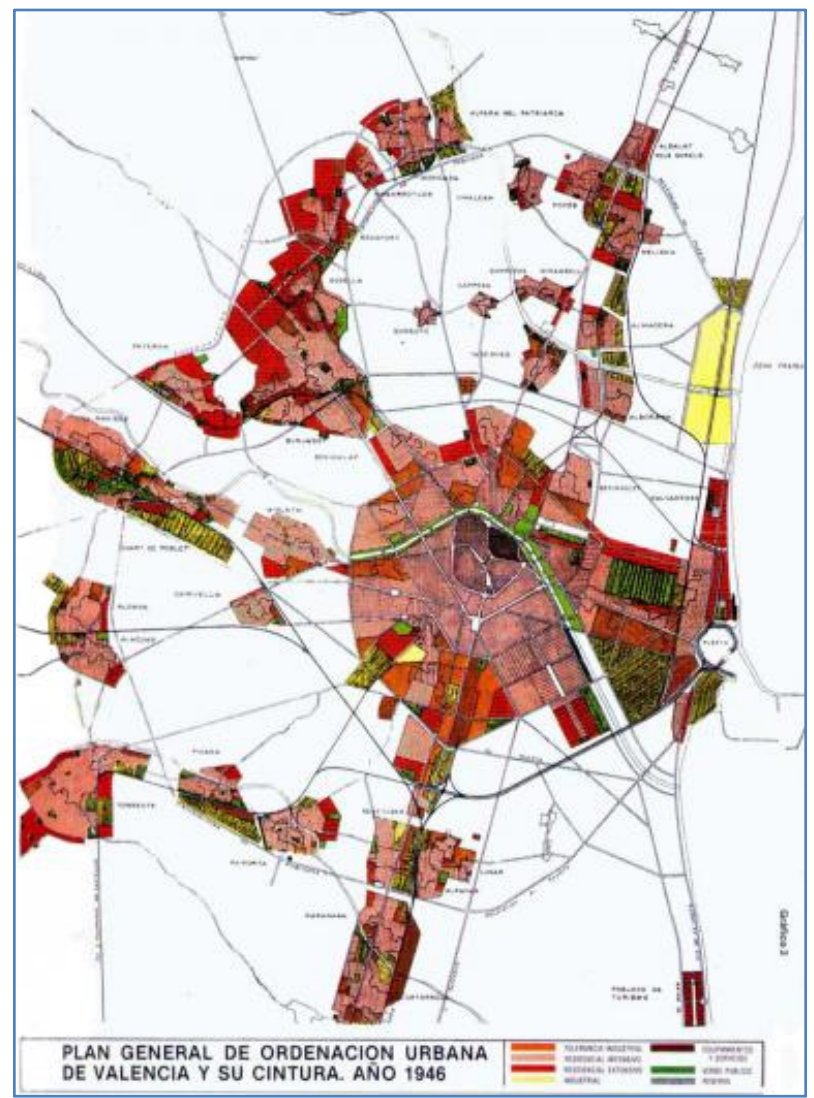

Figure 1: Metropolitan plan of Valencia, 1946. Origin: Historical Cartography.

At that time, the Spanish economy was autarkic. In consequence, one of the objectives of the plan was to reserve agricultural land for food production. The plan focuses urban development within the central and west areas, where the land 
is not adequate for agricultural activity. At this time, the motorization rate was very low with only 10 vehicles for every 1,000 inhabitants. There were no traffic problems.

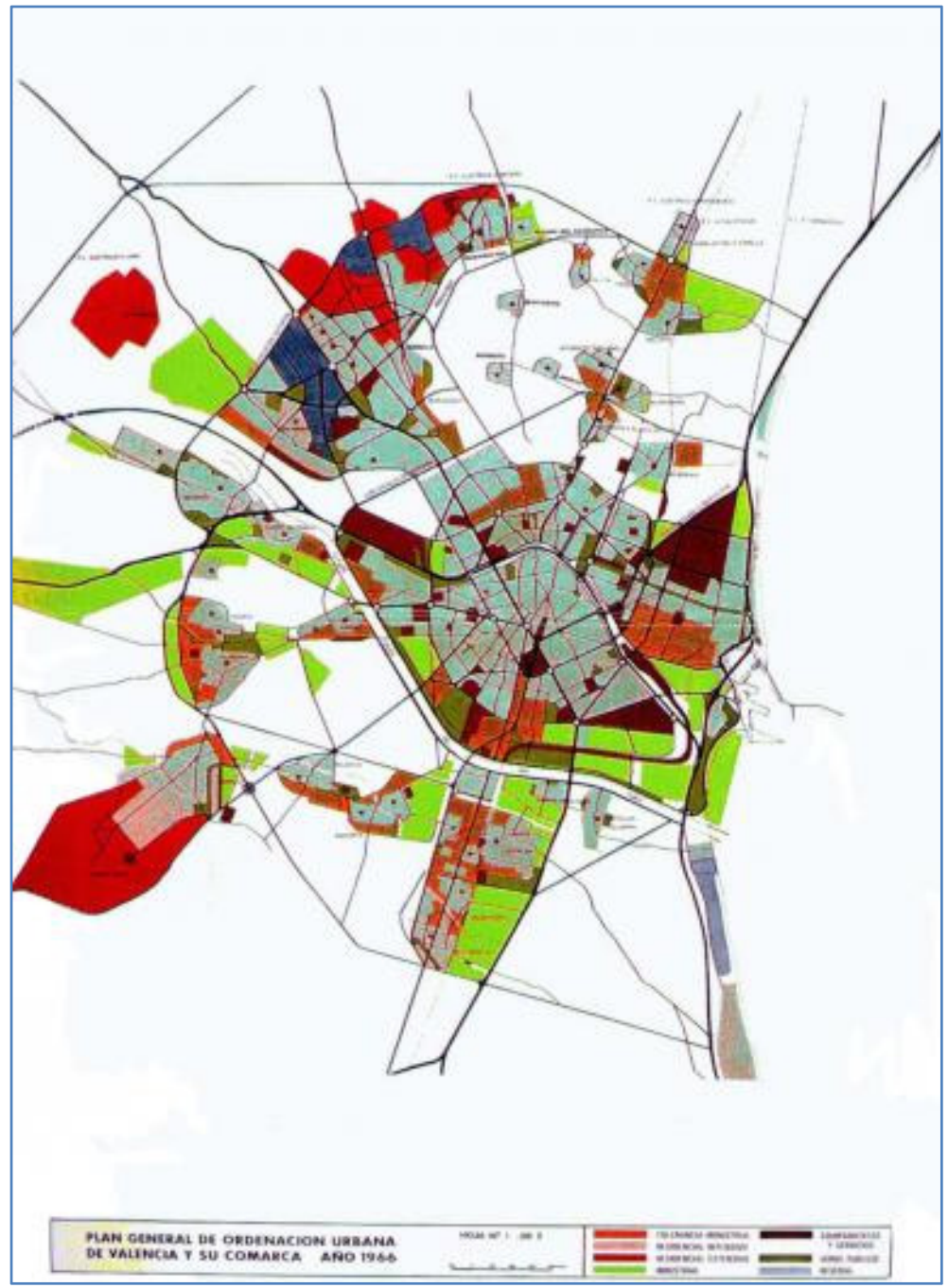

Figure 2: Second Metropolitan Plan of Valencia, 1966. Origin: Historical Cartography.

In 1959, Valencia suffered a serious flood caused by the Túria River. It was a huge catastrophe. Therefore, the government decided to change the course of the river to prevent similar disasters in the future. After a study of the solutions, the south solution was selected. The solution was to build a large canal in the south of the city to divert water and bring it to the sea. 
This great public work modified the conditions of regional planning. In 1966 a second metropolitan plan was approved, Plan General de Valencia y su comarca adaptado a la solución sur (General Urban Plan of Valencia and surrounding area adapted to south solution).

This second plan was elaborated during the first real estate bubble in Spain [2]. The economic plan of 1959 eliminated the autarkic situation and opened the country to foreign investment and tourism. This new situation for Spain produced a great entry of capital that generated a bubble. The investments in industry, tourism and construction produced important economic changes and a big urban development. In this situation the metropolitan plan of 1966 was oriented to planning a large growth in the city: population, houses and infrastructures, especially transport infrastructures. The Theory of Modern Architecture (Athens Cart of 1933) was introduced in Spain at this time and the traffic plan of the future cities was based on this as a symbol of economic progress. The trams, which made it difficult for car traffic in city centres, were eliminated in Spain around 1970.

The plan of 1966 foresaw major infrastructures for Valencia as a bridge over the harbour basin or major highway in the old riverbed bordered with skyscrapers next to the historical city.

\section{Urban planning in Valencia at the beginning of democracy}

The Democratic Constitution was approved in 1978. Administration is organized in three levels: local, regional and central. All levels have governments. Regional administration has legislative and executive power. Depending on the matters involved, the rules are approved by central legislative, regional legislative or central legislative approve basic rules and regional legislative complete the rules. Urban and regional planning matters are only regulated by regional legislative. Since 1978, Valencia has had many legal changes in the matters of urban and regional planning.

In 1986, the Corporación Administrativa Gran Valencia become extinct by the Act of Regional Government. In the same year, the Regional Government created the Consell Metropolità de L'Horta (L'Horta Metropolitan Council), a new metropolitan institution.

The new metropolitan institution elaborated the third metropolitan plan named Normes de Coordinació del Planejament dels municipis del Consell Metropolità de L'Horta (Planning Coordination Rules for municipalities of L'Horta Metropolitan Council). These rules were approved in 1988.

The rules are a general framework for municipal urban plans. The graphic rules in zoning plans (legally binding) was about:

- Landscape units

- Usefulness to urban development

- $\quad$ Flood risk and hydraulic public works

- $\quad$ Land reserves for public services and transport infrastructures reserves

- $\quad$ Road and rail networks

- Water infrastructures: supply, sewage and wastewater treatment 
This institution has always had management problems. All metropolitan municipalities had representation in Council but the major municipality, Valencia, had the majority of votes. In addition, regional government paid all the budget. Therefore, only the metropolitan works that regional government accepted, could be executed. In this situation the municipality of Valencia approved its urban plan in 1989. This plan is currently valid.

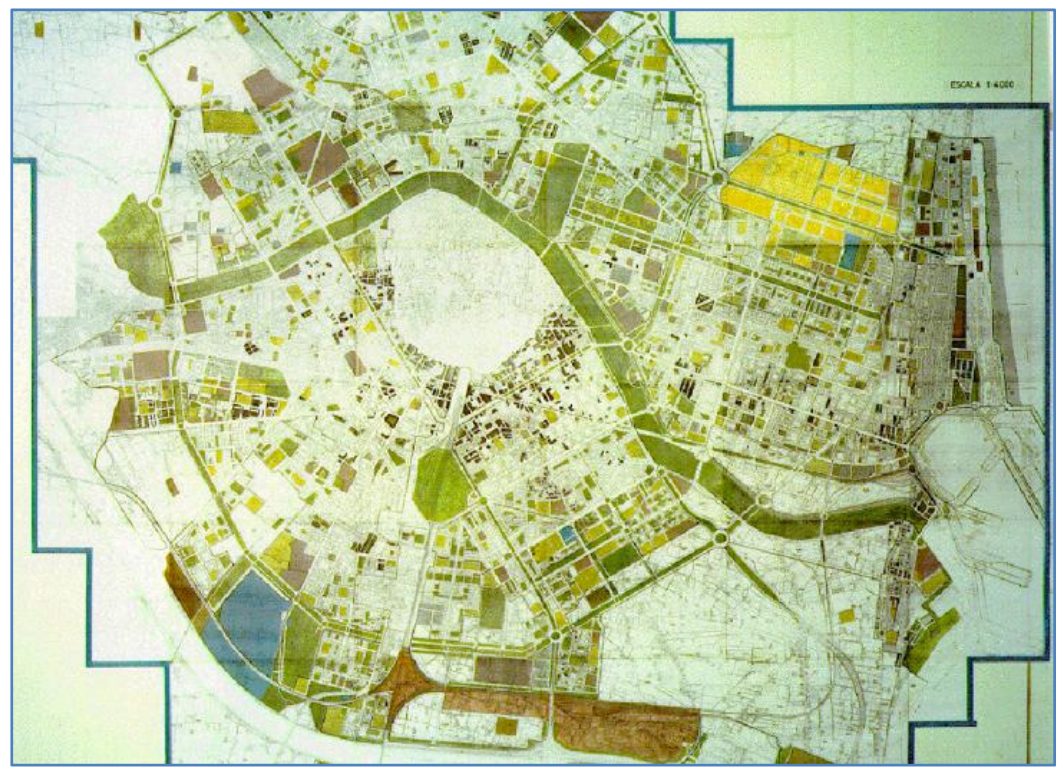

Figure 3: Urban plan of Valencia currently valid, approved in 1989. Origin: Municipality of Valencia.

This plan belongs to the group of major urban plans that were prepared in Spain in the early years of democracy. The main objective of the plan was to solve the deficit of public facilities of all kinds that existed at the time and to design the urban development of Valencia City.

Please note that the first housing bubble in Spain occurred in the period 1960 1972 [3]. The crash of this bubble was in 1972. The depressive cycle lasted until 1985. The second housing bubble occurred from 1985 to 1991.

The urban plan of Valencia was realized directly by municipality. The work began in about 1981. Therefore, all analysis was realized within a period of depression, with negative trends in social and economic indicators. Only from 1985 , trends changed and demands for building land increased. Finally the plan is a mix between proposals consistent with the analysis and an increase of land for building derived from previous demands.

One of the more important problems was the conflict between urban development and the preservation of agricultural land. That is, the conflict between urban use and agricultural use. In addition, how to design urban boundaries. 
Agricultural land in Valencia is a big extension of the historical fertile land called "L'Horta de València" and is located around the Valencian metropolitan area. It has agricultural land with high productivity, usually 3 or 4 crops a year. The extent of historical fertile land was about 10,000 ha. Today, more than half has disappeared due to urban development. This fertile land is irrigated by 7 historical channels. The origin of the channels is not known for sure, maybe Arabic (Valencia City has Roman origins). The Tribunal de las Aguas (Water Courts) administers justice among irrigators from the Arab period and King Jaume I recognized its jurisdiction in 1239 . The court works today and was declared World Heritage in 1999. In addition, another 10,000 ha of fertile land was irrigated more recently (about XIXs.).

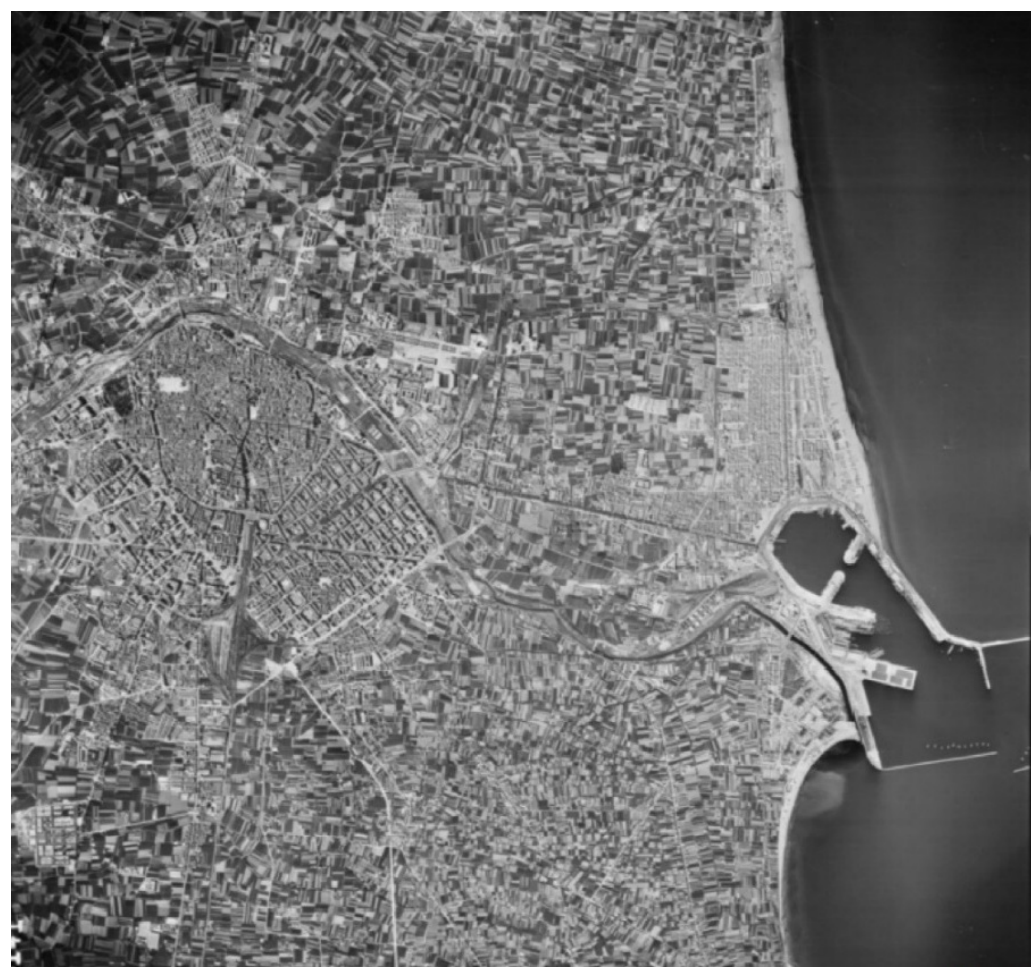

Figure 4: Aerial image, flight 1956. Origin: Generalitat Valenciana.

This conflict between uses was resolved, falsely, in the urban plan of 1989. The plan determined the transformation of about 800 ha of agricultural land and protected the rest of the agricultural land in the municipality of Valencia. But really, the process of urban development is irreversible while the protection is only an administrative situation. In fact, when governments change, so can laws and protections. For example, after 1989, a Logistic Zone (68.3 ha) near to the port of Valencia in a protected area named La Punta, was approved by a special procedure to unprotect the area where it was located [5]. 
The expansive economic cycle lasted until 1991 when the bubble burst and a new depressive cycle started that lasted until approximately 1997 approximately.

In 1995, regional government and territorial and urban policy was changed. In 1999 the Metropolitan Council of Valencia was closed but Metropolitan Rules of Coordination continued in force. From then on, municipalities could promote urban development in their own territory, they must comply with Metropolitan Rules but they haven't any institution to coordinate urban policy in the metropolitan area.

\section{New challenges for planning from 2000}

\subsection{Obsolete items of metropolitan rules}

Every plan becomes progressively obsolete. We can talk about three important issues that explain the obsolescence of the metropolitan plan of Valencia of 1988.

First, when metropolitan rules were written, technical specialists for the railways discussed closing or maintaining the railway network. Spain was out of the European Economic Community and needed to reduce public debt to join it. Management of rail services generated a large deficit. Finally, the political decision was in favor of maintaining public rail services and elaborating a modernization plan. In the metropolitan plan, there wasn't any reservation of land for new rail infrastructures.

Since about 1990, after Spain joined the EEC, the idea of high-speed rail emerged. The Spanish network railways has Iberian gauge, different to European gauge or UIC gauge. To enable connection of high-speed rail with the European railway network, it is necessary to build a new railway network with UIC gauge prepared for high-speed. The Valencia Metropolitan Plan hasn't any reservation for new railway projects.

Secondly, due to urban acts, local administration can have important income from urban development planning by the local urban plan. So, in general, all municipalities want to approve their urban plan to promote urban development. Municipalities, in this situation, do not want a metropolitan plan that places conditions on its urban development.

Finally, administration of metropolitan areas is very difficult. If you create a new administration level, between local and regional administration, its administrative power is only possible at the expense of decreasing powers of local and regional administration. Therefore, in general, local and regional administration do not want other administration levels, especially when the metropolitan area is very large in relation to the regional area as in the case of Valencia. Inhabitants of the metropolitan area of Valencia is about $33 \%$ of the inhabitants of the regional area.

\subsection{New infrastructures: high-speed rail, Mediterranean corridor for merchandising and harbour}

From 2000 a need for new infrastructures appeared. We have already talked about high-speed rail. In this case, as the metropolitan plan did not foresee the 
reservation of land for construction, new railways were projected avoiding built spaces, in the midst of farmland. Thus the agricultural land was fragmented.

At the moment, the new high-speed lines to connect Valencia-Madrid and Valencia-South are built. The Valencia-Barcelona line has not been built yet.

Another problem is the relationship between the port and the city. Valencia has an important sea port. Today, the port cannot grow northward or southward. North of the port is the beach of Valencia. And south of the port is the natural reserve of L'Albufera Lake. The port needs to have shore facilities. In addition, the old port is no longer useful for current port activities. Furthermore, the draft of the Mediterranean Corridor for merchandising is gaining supporters. Today the project approved by the EU as a priority, consists of a continuous line of European gauge railway that allows the transportation of merchandise from the Mediterranean ports to central and northern Europe.

All these projects needs a metropolitan vision to optimize localization of infrastructures with a global vision.

\subsection{Popular proposal to protect agricultural land}

Since about 1970, citizen movements arise in favor of protecting the agricultural land of L'Horta and against the urbanization of agricultural land to residential areas and infrastructure. These citizen movements have been active, with greater or lesser intensity, up to the present.

In 2000, a popular movement presented a legislative initiative in the regional Parliament of Valencia to protect the agricultural land of L'Horta. The initiative collected nearly 118,000 signatures (about $10 \%$ of the list of registered voters in the metropolitan area of Valencia) but was rejected. From these facts, successive governments have made initiatives to recognize the value of Valencia's agricultural land of L'Horta.

Since 2006, the regional government directly promoted a Territorial Action Plan for the Protection of L'Horta as an instrument to maintain agricultural land. The plan was completed in early 2011 but never was approved. Analysis and diagnosis about the situation of the agricultural landscape, realized for the plan was very extensive and rigorous.

In the initial official proposal, the idea was supplemented with a complementary economic agricultural plan and with a management institution [6].

\subsection{Attempt to change the urban plan of Valencia}

In 2004, Valencian urban laws changed with regard to regional planning but not building land. In 2005 the Valencian urban law with regard to building land changed. From this time Valencian urban laws were modified all years. Firstly in the final period of the housing bubble. After, in the period of crisis. In 2006 the Strategic Environmental Assessment was introduced in Spain, in pursuance of SEA Directive 2001/42/EC, two years later. The SEA procedure changed the administrative processing of urban planning completely. All these changes produced by different causes generated a long period of legal uncertainty with regard to the administrative approval process of urban plans. 
Valencia City began work to elaborate a new urban plan in about 2006, in the bubble period, with the objective of urban expansion by changing protected agricultural land to land for building. A first version of the new plan was shown to the public in 2008, the second version in 2010 and the third version was revealed in January 2015.

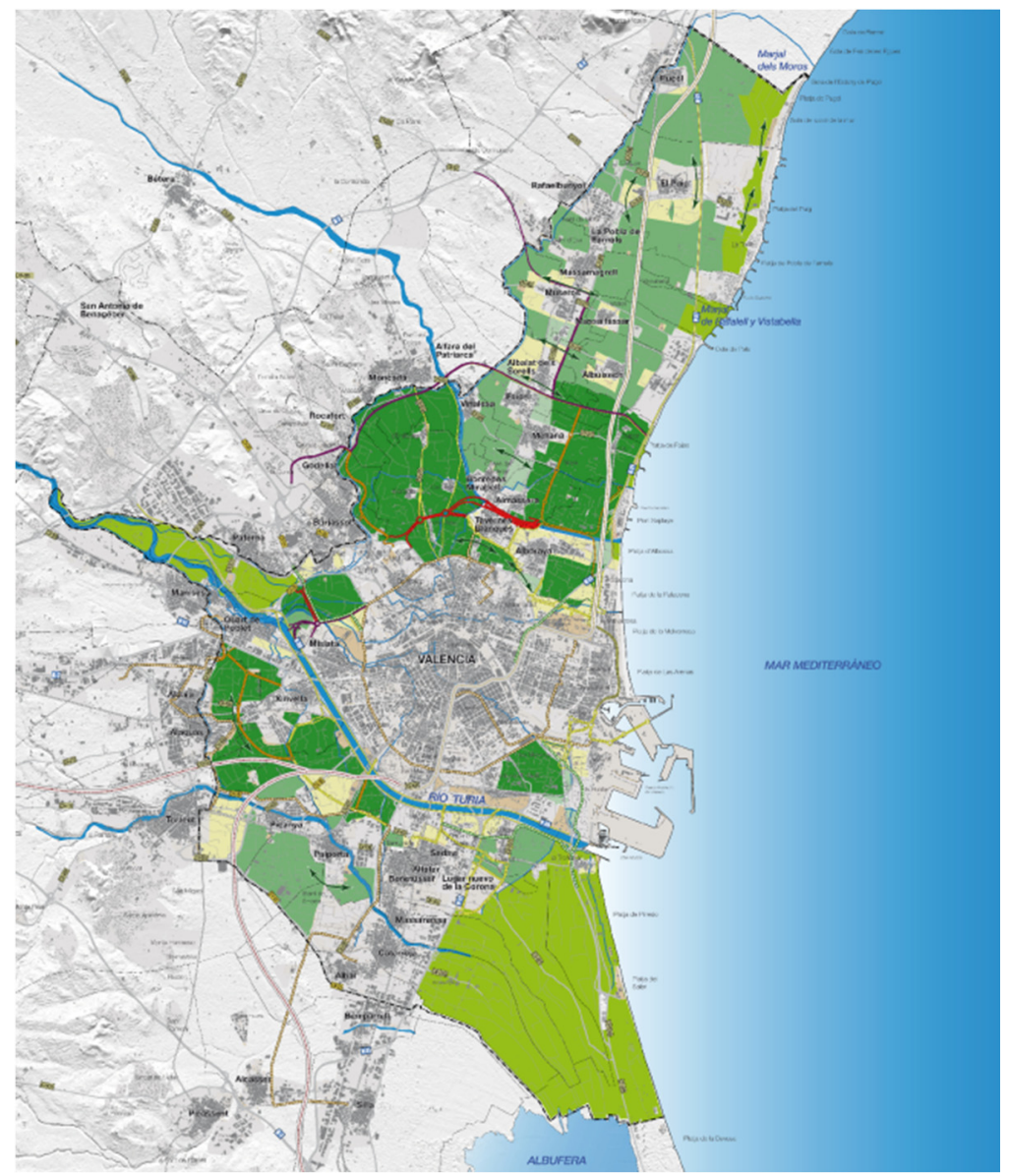

Figure 5: Zoning proposal in Territorial Action Plan for the Protection of L’Horta. Origin: Generalitat Valenciana, 2011.

The work on the first version were done in the housing bubble. Predictions made about increasing population and housing needs were much too high. In fact, according to statistical official dates [7] Valencia City had 805,307 inhabitants in 2006.

The report prediction foresaw an increase of 54,264 inhabitants for the period 2007-2018. But in fact, in 2014, Valencia City has decreased by 21,905 inhabitants. 
This real trend shows that the objective of the new urban plan can't be more expansion. Firstly because there is no need. Secondly, because the optimal location for a new possible uses must be analyzed in metropolitan area, not only in municipality of Valencia, without destroy natural resources as agricultural land. Last proposal of urban plan of Valencia has been strongly criticized.

\section{Structural changes from 2000}

\subsection{Globalization and financial bubble}

The process of economic globalization has allowed uncontrolled large sums of capital to move freely from state to state. In Spain, and especially in Valencia, there have been large capital investments in real estate through loans to developers and buyers [3]. These investments produced a large urban development, especially in the coastal cities of the Mediterranean coast. Often, real estate production was based only on expectations, not real demand [8].

This has led to cities with large empty urban spaces and buildings without use. We need to rethink new efficient instruments for management and planning of the consolidated city.

\subsection{Technology and administration}

Technology has changed a lot, especially communication technologies. When cities arose in ancient times, communication between people was only possible through direct personal relationships. There were no other technologies and there were no other types of communication. We can speak well of "dcity" [9].

From the nineteenth century a great development of transportation systems in the world was produced. This allows the extension and dissemination of the city. New means of transport allow people to work together that live further apart. The phenomenon of large metropolitan areas and large urban areas appeared. Relationships that allows transport do not replace the personal relationship they complement. The historic town remains an element of identity, and economic and social activities are based on direct relationships and extensive use of transport. We can speak well of "tcity".

Finally, since a few years ago, the internet network allows daily relations among people unrelated. People can relate regardless of where they are. Innovation and division and organization of work can be done, in fact, without physical presence. But again, these relationships do not replace but complement earlier relationships. Simultaneously, the network provides access to vast amounts of information. We can speak well of "ecity", a city without geography.

Consequently, the reality of the territory has changed and efficient administration requires new forms of management. Spain has pending reform of its administration to adapt to the current situation. We can imagine an administration on three levels, the level of community or dcity level, the level of functional area or tcity/ecity level and regional level. The action of the administration is distributed according to the technology required to be used. 


\subsection{Urban sustainability}

We all know the concept of sustainability but do not yet have a set of clear and objective criteria for the efficient implementation of the concept in the city. In fact when we speak about urban sustainability, scientists speak about a large list of issues that we can improve [10]. In fact, it is very difficult to realize a "sustainable" urban plan because a subject is still in motion with different issues.

However, we can fix a specific topic: land uses in territory. In this subject, the concept of Green Infrastructure is progressively developed in Europe. Finally, the European Commission has adopted a Green Infrastructure Strategy "to promote the deployment of Green Infrastructure in the EU in urban and rural areas" [11].

An important problem of our cities is the design of borders, especially the contact between city and rural land [12]. That is the case with Valencia and its agricultural land. The concept and European policy about Green Infrastructure will help to integrate urban and rural lands.

\section{For a new type of plan}

According to the analysis, I propose suggestions about the new type of plan. The suggestions are written under the hypothesis that economic progress cannot always be based in urban development or continuous growth. In this situation, the urban plan must be focused on rethinking urban uses in the consolidated city, increasing efficiency and attraction, especially in the tourist city on the coast.

Only one urban plan cannot plan for all issues of sustainability on the cities. So we need a basic plan complemented with other plans. As a basic plan we can consider a regional plan focused on urban developed uses for functional area level. The contents of the basic plan should be clearly defined by law. At this level, the first thing to pinpoint will be green infrastructure that determines the basic situation for other infrastructures. Infrastructures such as high-speed railway, merchandise railways, harbor, road network... must also be agreed at this level after green infrastructures have been agreed. It is necessary for a management system to guarantee Natural Capital, as a green infrastructure, for long term. It cannot depend on the government for each moment.

Cartographic technologies have changed a lot. New urban plans should exploit their potential. But new technologies need a minimum size of the service to be useful.

Complementarily we can have an urban plan focused only in the consolidated city to plan urban renovation. In this case the level for action will be the city or the dcity. The dcity can be similar to the pedestrian community experimented in Barcelona [13]. This type of urban plan can be complementary with others (mobility, houses...) but by different procedures. An especially important plan on the coast can be landscape plans. To date, an urban plan in the coastal municipalities was based on urban development which, for a long time, generated mass tourism and falling incomes. By contrast, it is better to attract by landscape plans to fix tourism with medium or high income.

The efficient management of building plots requires a review of the theory of propriety of land to build. The rebuilding of a plot with many co-owners is 
practically impossible. The administrative procedures must be efficient. The plans, in general, must be elaborated and approved in 2 or 3 years, not more.

\section{Conclusions}

Our world has changed a lot in recent years. It is necessary to adapt the urban plan to the current situation. But urban planning is an action of administration, so it is also necessary to adapt administration for efficient planning with new technologies.

\section{References}

[1] Miralles i Garcia, J.L. The Planning of Peri-Urban Agricultural Areas: the Case of L'Horta de Valencia. Proc. of Real Corp 2013. Planning times, eds Manfred Schrenk, Vasily Popovich, Peter Zeile \& Pietro Elisei: Rome, pp. 953-962, 2013.

[2] Miralles i Garcia, J.L. Real estate crisi and sustainability in Spain. WIT Transactions on Ecology and Environment. Vol. 150, WIT Press: Southampton, pp. 123-133, 2011.

[3] Miralles i Garcia, J.L. El darrer cicle immobiliari al País Valencià. O el progrés de la misèria. Fundació Nexe: València, 2014.

[4] Generalitat Valenciana. http://fonoteca.icv.gva.es

[5] Compés López, R. El Puerto de Valencia y su Zona de Actividades Logísticas. Revista Valenciana d'Estudis Autonòmics, Num 25, pp. 261280, 1998.

[6] Muñoz Criado, A. Plan de la Huerta de Valencia. Un paisaje cultural milenario., vol. 1, Estrategias de Preservación y Gestión. Generalitat Valenciana. Conselleria de Medi Ambient, Aigua, Urbanisme i Habitatge: Valencia, 2009.

[7] Instituto Valenciano de Estadística. Generalitat Valenciana. www.ive.es

[8] Miralles i Garcia, J.L., Díaz Aguirre, S. \& Altur Grau, V., Environmental impact on the Mediterranean Spanish coast produced by the latest process of urban development. WIT Transactions on Ecology and The Environment, Vol 155, WIT Press: Southampton, pp 379-389, 2012.

[9] Miralles i Garcia, J.L. The e-city or the city on the cloud. Proc. of Real Corp 2014. Plan is smart, eds Manfred Schrenk, Vasily Popovich, Peter Zeile \& Pietro Elisei: Vienna, pp. 675-684, 2014.

[10] Hagan, S. Ecological Urbanism: the nature of the city. Routledge: Oxon, 2015.

[11] European Commission. http://ec.europa.eu/environment/nature/ ecosystems/index_en.htm

[12] Allen, A. Environmental planning and management of the peri-urban interface: perspectives on an emerging field. Environmental and Urbanization, Vol 15, pp. 135-147, 2003.

[13] Agència d'Ecologia Urbana de Barcelona. Conceptual model: http://bcnecologia.net/en/conceptual-model 